\title{
7. France: dominant leadership
}

\author{
Natalie Windle
}

\section{Crisis as leadership opportunity}

The issue of political leadership in France has drawn a great deal of media and public attention since Nicolas Sarkozy was elected President on 6 May 2007-not least during the French Presidency of the European Union during the second half of 2008. This period saw Sarkozy take the reins of European leadership and acquire the moniker 'Super-Sarko'. Sarkozy's confident and fast-paced leadership not only drove the broad political agenda of the European Union during those six months, it faced the challenge of the heightened severity of the global financial crisis, which initially surfaced in August 2007. Moreover, the catchphrase 'the European Union brings force' ${ }^{1}$ rang very true for Sarkozy, whose message was heard more widely when he spoke on behalf of the European Union than when speaking for France alone (Missiroli 2009). The EU platform thus played a significant role in the framing of the global financial crisis in France, especially from Sarkozy's perspective.

On the domestic front, the crisis manifested itself in France most notably from September 2008, triggered by the collapse of the investment firm Lehman Brothers in the United States, which sent shockwaves around the globe. In France, Fortis stock collapsed on 26 September as confidence in its solvency fell and, four days later, the French, Belgian and Luxembourg governments committed $€ 6.4$ billion towards the rescue of the bank Dexia. In the 12 months before these events, the sub-prime crisis in the United States had already damaged the international financial sector. In this environment, France had been taking more precautionary measures such as 'the law for economic modernisation', 2 which was aimed primarily at simplifying French small and medium businesses (SMEs). ${ }^{3}$ The crisis, however, put such initiatives on hold as more immediate measures were taken to ensure the continued financing of the economy. At the close of 2008, Sarkozy announced a stimulus plan totalling $€ 26.4$ billion, to be spent on public investment projects across many sectors within the next year.

In the following analysis of the French elite's rhetoric on the financial crisis, the focus remains on three key actors: the President Nicolas Sarkozy, the Minister for the Economy, Industry and Employment Christine Lagarde, and the Governor of the Banque de France Christian Noyer. All three actors held these offices throughout the period of analysis - April 2008 to March 2009 - with Sarkozy and Lagarde taking their posts from the May 2007 election and Noyer being appointed the governor in November 2003. The period of analysis is situated in 
the early to mid-term of the French electoral cycle, with the next elections due in 2012. The quinquennat (five-year term) is relevant to this case study as the longer-term crisis management of the incumbent government will likely be a critical consideration in the 2012 election.

Sarkozy entered his presidency with high popularity ratings, reaching 65 per cent in the first month (CNN 2007), indicating confidence in his leadership during 'normal times'. This phase-two period is, however, indicative of his leadership capabilities in a time of crisis. The first of President Sarkozy's speeches analysed in this chapter, from 25 September 2008, was referred to by a journalist for Le Figaro as 'a speech which incontestably marks the start of the second phase of the five year term' ${ }^{4}$ (Jeudy 2008). Sarkozy's leadership is a clear focus of this analysis, which aims to address the beginning of phase two and how it has impacted on public and media opinions.

\section{Box 7.1 France's financial crisis trajectory, April 2008 - March 2009}

28 April 2008: Minister for the Economy, Industry and Employment Christine Lagarde, holds a press conference to present a plan for the law of economic modernisation.

I3 May: While travelling to Vienna, President Sarkozy reassures artisans and small shopkeepers that the law for economic modernisation will simplify the process of owning your own business. On the broader economic situation, rising prices are not a 'fatality', according to Sarkozy.

I5 May: Lagarde congratulates the remarkable resistance of the French economy in the first quarter of 2008, especially the vigour of investments, which are up to 1.8 per cent from 1.2 per cent in the fourth quarter of 2007. The French produit intérieur brut (PIB, or gross domestic product [GDP]) progresses to 0.6 per cent in the first quarter of 2008, according to the National Institute of Statistical and Economic Studies (l'Insee), which also reviews a rise of 0.2 points on the growth of 2007, to 2.1 per cent.

27 May: A freeze is put on property sales. ${ }^{5}$ According to recent figures from the Ministry for Development, sales dropped to 27.9 per cent in one year, between January and March.

29 May: Natixis, the French corporate and investment bank whose primary shareholders are Banque Populaire and Caisse d'Épargne, announces the suppression, in the next 18 months, of 1100 jobs, of which 850 are in France.

2 June: Presentation of the economic modernisation bill to the National Assembly by Finance Minister Lagarde. 
II-I2 September: EuroFin Conference in Nice, organised under the French EU Presidency and chaired by Lagarde.

26 September: Financial giant Fortis's stock collapses. Fortis is refloated on 29 September by Belgium, the Netherlands and Luxembourg (the Benelux states). BNP Paribas takes control of Fortis in Belgium and Luxembourg for $€ 14.5$ billion.

3o September: The governments of Belgium, France and Luxembourg underwrite the rescue of the top-tier retail bank Dexia by subscribing to an increase in capital of $€ 6.4$ billion to keep it afloat.

Io October: The French Government promises $€ 320$ billion in state-guaranteed lending to banks and $€ 40$ billion to recapitalise any bank in difficulty.

I2 October: At the initiative of President Sarkozy, Paris adopts the European anti-crisis plan based on the protection of savings, financing the economy and avoiding financial institutions' bankruptcy.

I8 October: Sarkozy and José Manuel Barroso, President of the European Commission, meet with US President, George W. Bush, to discuss the redesign of the world's financial structure.

23 October: In a speech at Argonay, Sarkozy announces a meeting of the G20 as well as a new strategic investment fund involving $€ 26$ billion of loans, in order to assure the financing of the French PME.

7 November: EU summit is held, at which a common set of principles for reform of the International Monetary Fund (IMF) is agreed on.

20 November: Between 163,000 and 220,000 French teachers and tertiary and high school students protest against the loss of jobs and education reforms.

4 December: Sarkozy announces a stimulus plan to boost the French economy with $€ 26.4$ billion ( 1.3 per cent of GDP) to be spent on public sector investments and loans for France's automotive industry.

6 December: A Le Monde opinion poll suggests that 71 per cent of respondents do not believe the Socialist Party has a 'vision' for France. The Socialist Party was struggling to mount an effective response to the crisis.

Io December: After the announcement of a fall in private consumption, a rise in unemployment and a commercial record deficit, Insee reveals a dive of 2.7 per cent in overall industrial production in October. 
20 January 2009: Prime Minister, Francois Fillon, announces the government's intention to provide €5-6 billion to aid struggling car manufacturers.

9 February: German Chancellor, Angela Merkel, and Sarkozy propose a meeting of the $27 \mathrm{EU}$ member states. Sarkozy announces that two French automobile manufacturers, Renault and PSA Peugeot-Citroen, will receive $€ 6$ billion in state loans, on the condition that they do not close factories in France.

Io February: Fillon unveils a stimulus package involving 1000 projects across France; 75 per cent of the allotted $€ 26$ billion must be spent by the end of 2009.

24 March: Sarkozy delivers an address at Saint-Quentin, defending his economic policy and promising to go even further.

\section{Methodological considerations}

This chapter is designed in line with three key approaches outlined in Chapter 2 of this volume. Specifically, it covers a 12-month period beginning in April 2008, and presents: an interpretation of leaders' speeches addressing the financial crisis; the public and media responses to these speeches; and a crisis-exploitation analysis of the elite actors' framing efforts. President Sarkozy, Minister for the Economy, Industry and Employment, Christine Lagarde, and Banque de France Governor Noyer were selected on the basis of their key roles in managing the crisis. The Prime Minister, Francois Fillon, though a key player in the French Government, was not included in this analysis because his visibility in the crisis was eclipsed by the dominant presence of Sarkozy. The actors' key speeches were then chosen according to the following criteria: focus, audience and response. Each of the key speeches analysed in this study maintained a focus on the financial crisis and was addressed to an audience for whom the crisis was an issue of high importance. They also received a significant amount of coverage in the media, though this was the most true for Sarkozy.

Second, this chapter provides an empirical analysis through media and public responses to the leaders using four daily newspapers and public opinion data. According to popularity and circulation numbers, the three major daily newspapers in France are Le Monde, Le Figaro and Libération, with respective circulations of 440,000, 330,000 and 135,000 (The Connexion 2009). A fourth daily newspaper, Les Echos, which could be likened to the Financial Times and the Wall Street Journal, was chosen for its position as a major financial and economics daily, with a circulation of 120,000 (About-France 2009). Le Monde was established in 1944 by General Charles de Gaulle and is viewed as a centre-left publication. Le Figaro has a much longer history, dating back to 1826 , 
and is a relatively conservative newspaper. Libération was founded in 1973 by Jean-Paul Sartre for the 1968 generation, and holds a more socialist position (The Connexion 2009).

To measure media responses to the actors' speeches, daily newspapers were referenced and presented according to their (dis)agreement or neutrality towards each leader and how they framed the crisis in terms of causality, severity and policy proposals. In addition to the media response, Le Figaro-LCI Politoscope, which published weekly surveys regarding domestic and international political events, was utilised as a resource to gauge French public opinion. The surveys engage 900-1100 people each week, through an online system called Cawi (computer-assisted web interview), and compile the results along with quotas for age, sex, socio-professional category and residential region (Le Figaro-LCI Politoscope 2008). Last, by utilising the crisis-exploitation framework and considering contextual factors unique to the French case, this chapter aims to shed light on the unfolding of the French manifestation of the global financial crisis and the framing of the crisis by three key individuals: Nicolas Sarkozy, Christine Lagarde and Christian Noyer.

\section{Crisis development and elite rhetoric in France}

Nicolas Sarkozy, though originally trained as a barrister with a master's degree in private law, has had a long career in the French Public Service, beginning with his position as Mayor of Neuilly-sur-Seine from 1983 to 2002. During this time, he was also Minister for the Budget (1993-95) and Minister for Communications (1994-95). Sarkozy was elected to his current position as President of the French Republic with 53 per cent of the votes on 6 May 2007. He was the key government voice on the crisis for the French audience, as well as on the European stage while France held the rotational EU Presidency from July to December 2008.

Christine Lagarde rose to senior management positions at the international law firm Baker \& McKenzie. In June 2005, she was asked by then French Prime Minister, Dominique de Villepin, to join his government as Minister of Foreign Trade. After a cabinet reshuffle, she became the first woman in a G7 country to hold the post of Finance and Economy Minister (EuroFin 2008). A former head of the French Treasury, Christian Noyer was appointed Vice-President of the European Central Bank (ECB) in 1998. His international experience included work with the European Monetary Committee, the Organisation for Economic Cooperation and Development (OECD), G7 and G10 and positions as alternating governor at the IMF and World Bank. In November 2003, he was appointed Governor of the Banque de France (Banque de France 2004). 


\section{June 2008: the bank governor's early diagnosis}

Noyer's first key address in relation to the global financial crisis came in June 2008. The day before the Banque de France annual report was released, Noyer addressed the General Assembly of the Office of Bank and Financial Coordination. Contextually, this can still be considered the pre-crisis phase in the French economy. The symptoms of the sub-prime crisis had remained largely contained to the United States and the United Kingdom, although its effects had been seeping through the international financial sector.

Noyer defined the cause of the problems as mismanagement of the system. 'This situation originated in a general perception that investment opportunities in assets, apparently of good quality, were almost unlimited, and this altered the judgement of actors' ${ }^{\prime}$. In this speech, Noyer proposed 'an ensemble of good practices $^{7}$ more than specific policy proposals. For example, he affirmed the importance of the role of governance in terms of managing risk, as well as conveying that the banks that were best equipped to respond to challenges were those that invested early in developing evaluation and control procedures and developed their knowledge of the risks inherent in complex products. The media response to this address was largely neutral towards Noyer's framing of the crisis and his leadership, although there was some disagreement with his portrayal of the severity of the crisis (Table 7.1). An article in Le Figaro expressed this disagreement, saying 'even though on the stock exchange, banks have been seriously mismanaged, the Bank Commission wants to be more optimistic' 8 (Bohineust 2008).

\begin{tabular}{|l|l|l|l|l|}
\hline & Causality & Severity & Proposals & $\begin{array}{l}\text { Support for } \\
\text { speaker }\end{array}$ \\
\hline Agrees & 1 & & 2 & \\
\hline Disagrees & & 2 & & 6 \\
\hline $\begin{array}{l}\text { No comment/ } \\
\text { neutral }\end{array}$ & 5 & 4 & 4 & 6 \\
\hline
\end{tabular}

Table 7.1 Media response to Noyer's 25 June 2008 speech

\section{September 2008: Sarkozy's Toulon address}

President Sarkozy's address at Toulon in September 2008 came on the heels of the collapse of Lehman Brothers in the United States. This event was a watershed event in the financial crisis. In France, this marked the escalation of the national crisis. Sarkozy's approach at Toulon was twofold: he highlighted the uniqueness of the crisis and he made a call for a new international financial order. From the outset, Sarkozy labelled the crisis 'a crisis of confidence without precedent'. 9 He did, however, make a reference to the depression of the 1930s, noting the current crisis had seen no equivalent since. The majority of the population - those 
under the age of seventy - had not experienced the 1930s depression, so Sarkozy effectively conveyed the uniqueness of this crisis as the first of its kind in most peoples' lifetimes. After this introduction, Sarkozy highlighted the pitfalls of the system that caused the crisis. 'The financial crisis is not the crisis of capitalism. It is the crisis of a system which did away with the most fundamental values of capitalism, which in some sense, betrayed the spirit of capitalism' ${ }^{10}$

According to Sarkozy, capitalism had allowed the rise of the West throughout seven decades, but a betrayal of capitalist values had emerged. Having established its corruption as the fundamental cause of the crisis, Sarkozy proposed the reform of capitalism, because 'anticapitalism does not offer any solution to the actual crisis' $^{\prime 1}$. Sarkozy's plan for a new equilibrium between the market and the State started with the regulation of the banks and controlled remuneration. He insisted that the severity of the crisis was substantial, labelling it the end of the post-Cold War capitalist world.

This address is vital to understanding Sarkozy's framing of the crisis because he illustrates the situation in terms of its exceptionality. Effectively, his message was that in an exceptional case, one called for an exceptional response. The media responded to this address with overall support for Sarkozy, but also with some concern about his policy proposals (Table 7.2). Most notably, the media acknowledged the significance of this speech. Le Figaro referred to it as 'the day when Sarkozy called for mobilisation against the crisis' ${ }^{12}$ (Jeudy and Visot 2008). Les Echos mirrored this perspective, saying, 'Nicolas Sarkozy's discourse pronounced at Toulon on 25 September marks his entry into the war against the crisis $^{\prime 13}$ (Cornudet 2008). The Toulon address was undoubtedly Sarkozy's first attempt at crisis exploitation in the face of a financial crisis that had worsened in the national economy.

Libération called Sarkozy's 'classic allocution' messianique in his wish to be heard by the French, who feared for their economy (Guiral 2008). This fear was real, as demonstrated by a poll conducted by Ifop on 18-19 September, which indicated that 81 per cent of French respondents were concerned about the French economy in the financial crisis (Angus Reid Global Monitor 2008). Sarkozy's attempt at crisis framing in the Toulon address failed to reassure the concerned French public, as evidenced by a CSA survey published in the newspaper Le Parisien on 28 September, which showed that 51 per cent of those surveyed did not have confidence in Sarkozy to reduce the impact of the crisis in France (Les Echos 2008). 


\begin{tabular}{|l|l|l|l|l|}
\hline & Causality & Severity & $\begin{array}{l}\text { Policy } \\
\text { proposals }\end{array}$ & $\begin{array}{l}\text { Support for } \\
\text { speaker }\end{array}$ \\
\hline Agrees & 1 & 7 & 2 & 6 \\
\hline Disagrees & & 1 & 5 & 3 \\
\hline $\begin{array}{l}\text { No comment/ } \\
\text { neutral }\end{array}$ & 8 & 1 & 2 & \\
\hline
\end{tabular}

Table 7.2 Media response to Sarkozy's 25 September 2008 speech

\section{September 2008: Finance Minister Lagarde's budget speech}

One of Lagarde's first public speeches after the manifestation of the crisis in France was delivered ahead of the upcoming budget for 2009. From the outset, Lagarde looked past the short term and framed the crisis beyond 2008-09. She noted that 'the plan for programming public finance effectively brings us to $2012^{\prime 14}$. This foresight acknowledged the severity of the crisis at hand, which demonstrated that Lagarde's was not a type-1 'business-as-usual' frame, but rather a type-2 frame of crisis acknowledgment.

Lagarde maintained a matter-of-fact tone throughout this speech, conveying the grim financial projections but simultaneously reassuring that the eurozone was better situated than the US economy. With this comparison with the United States, Lagarde defined the crisis as one without precedent and also accounted for its origins in the US financial sector. 'The turbulences endured by international financial markets over the past year reflect the consequences of a deep purge of the American financial sector ${ }^{15}$. Lagarde outlined the various proposals of the French Government for the five-year period to 2012, which included structural reforms for employment policy (targeted at employment candidates, seniors and youth), buying power, economic modernisation and a tripling of the research tax credit (CIR).

The media response to Lagarde's presentation of the 2009 budget was focused primarily on public deficit figures and proposed policy, and there was neither support nor opposition expressed towards Lagarde herself (Table 7.3). There was implicit agreement with the severity of the crisis and its impact on the budget. For example, an article in Le Figaro agreed that the financial crisis had weakened the French economy. 'The financial crisis which has raged for one year has finally impacted the global economy and provoked a net slowdown in France $^{16}$ (Lachevre and Visot 2008a).

One particular policy proposal that was criticised in the representative media response was related to civil servants. Le Monde stated that '30 600 jobs would be done away with in the public service compared to 20900 in 2008 . This is a little less than the promise of not replacing one for every two civil servants who 
leave for retirement' ${ }^{\prime 7}$ (Lachevre and Visot 2008a). This argument was well founded in the context of uncertainty about rising unemployment and it also brought to the fore the credibility of the government by questioning its commitment to its promises. On the whole, the media response to Lagarde's presentation of the budget was critical of the government's approach to the weakened economic conditions in France, but paid little attention to Lagarde herself.

\begin{tabular}{|l|l|l|l|l|}
\hline & Causality & Severity & $\begin{array}{l}\text { Policy } \\
\text { proposals }\end{array}$ & $\begin{array}{l}\text { Support for } \\
\text { speaker }\end{array}$ \\
\hline Agrees & & 4 & 1 & \\
\hline Disagrees & & & 3 & 4 \\
\hline $\begin{array}{l}\text { No comment/ } \\
\text { neutral }\end{array}$ & 4 & & & 4 \\
\hline
\end{tabular}

Table 7.3 Media response to Lagarde's 26 September 2008 speech

\section{October 2008: Lagarde presenting a recovery plan}

Lagarde's next key address was delivered to the Senate and was titled 'National plan for assuring the financing of the economy and restoring confidence' ${ }^{18}$ In the opening lines of this address, Lagarde defined the financial crisis in the following terms: 'the crisis through which we are living is excessive.' ${ }^{19}$ This crisis of excess was explained by four factors: the excess of speculation, the excess of credit in the United States, the excess of complexity in which the financial profession lost control of the tools it created and the excess of irrationality and panic on the stock exchange.

Lagarde then proceeded to outline the government's proposal for management of the crisis. The proposal was threefold: first, the creation of a society of refinancing whereby funds would be raised with a state guarantee; second, the possibility of the State reinforcing the equity capital of French banks; and third, the Dexia guarantee in cooperation with Belgium and Luxembourg. On the first point, Lagarde made note of a marked contrast with the plan proposed by US Treasury Secretary, Henry Paulson, saying 'our proposal is completely opposite to the Paulson plan...the American state proposes to take control of the worst assets...in France, the state will not buy the assets. It will loan to the banks. ${ }^{20}$ This contrast was paramount in Lagarde's greater narrative, which insisted that France remained in a better financial position than many other nations, especially the United States.

The media response to Lagarde's 15 October speech was similar to that to her 26 September address in terms of the focus on government policy, rather than on Lagarde herself. Lagarde was effectively viewed as the representative or spokeswoman for a larger decision-making body. Most notable among the media 
responses illustrated in Table 7.4, Le Figaro conveyed agreement with the proposed policy because it would go a step further than other plans adopted in Europe and the United States: 'French measures can serve to achieve two purposes by helping business to refinance themselves in the mid-term' ${ }^{21}$ (Lachevre 2008).

\begin{tabular}{|l|l|l|l|l|}
\hline & Causality & Severity & $\begin{array}{l}\text { Policy } \\
\text { proposals }\end{array}$ & $\begin{array}{l}\text { Support for } \\
\text { speaker }\end{array}$ \\
\hline Agrees & & 1 & 1 & \\
\hline Disagrees & & & 2 & 3 \\
\hline $\begin{array}{l}\text { No comment/ } \\
\text { neutral }\end{array}$ & 3 & 2 & & \\
\hline
\end{tabular}

Table 7.4 Media response to Lagarde's 15 October 2008 speech

\section{October 2008: Noyer's struggle to be heard}

Christian Noyer delivered a noteworthy address titled 'Reflections on the crisis' in October 2008. In the months since his address to the General Assembly of the Coordination Office, Noyer had been curiously absent from the public eye.

After this gap in public presence, Noyer continued his framing of the crisis at an address to the Crédit Agricole Congress on 21 October. According to Noyer, at this time, there were two certainties about the crisis: it would impact on the economy in the long term and it was defined as a crisis of liquidity. Noyer directed the focus away from the government's leadership, towards the role of central banks, which effectively stood 'in the front line ${ }^{22}$ during the combat. Noyer organised his speech around four themes: the nature of the crisis, the policies put in place to manage it, the macroeconomic perspectives and financial regulation perspectives. On the last two themes, he reinforced that the fall in confidence was not centred on France, and he promoted the value of a deep knowledge of the banking sector, not only at the microeconomic level but in terms of limiting risk across the entire global system. His overarching message maintained that French banks were solid and profitable and he demonstrated support for Sarkozy's push to organise Europe's crisis response. ${ }^{23}$

After his address at Nice, Noyer was presented by Le Monde as a timid figure in the shadow of Sarkozy, with the paper saying he was inaudible in a room of 100 people $^{24}$ (Bacqué 2008). This was one of the very few articles that focused on the personality and leadership of Noyer himself, as most of the media and public attention was engaged with policies in the banking sector rather than its key actors (Table 7.5). Overall, there was more opinion on France's banking policy than on the governor himself (Ganiko 2009). The article in Le Monde on 24 October detailed Noyer's background and provided a very positive character reference as well as crediting Noyer with the plan for the bank guarantees. 


\begin{tabular}{|l|l|l|l|l|}
\hline & Causality & Severity & $\begin{array}{l}\text { Policy } \\
\text { proposals }\end{array}$ & $\begin{array}{l}\text { Support for } \\
\text { speaker }\end{array}$ \\
\hline Agrees & & & & 1 \\
\hline Disagrees & & & 2 & 1 \\
\hline $\begin{array}{l}\text { No comment/ } \\
\text { neutral }\end{array}$ & 4 & 4 & 2 & 2 \\
\hline
\end{tabular}

Table 7.5 Media response to Noyer's 21 October 2008 speech

\section{October 2008: Sarkozy's Argonay address}

One month after his Toulon address - and also subsequent to the Dexia rescue on 30 September 2008 by the French, Belgian and Luxembourg governments - Sarkozy delivered a key speech at Argonay. Conveying the truth to the French people was the dominant theme of his speech. Sarkozy reiterated the exceptional circumstances, also confirming that it was a global and not a French, or European, crisis. This effectively exogenised the cause and origin of the crisis. Building on his speech at Toulon in September, Sarkozy pinpointed responsibility for the crisis to the faults and errors of financial institutions. In advancing his declaration of the end of the post-Cold War capitalist world, which was introduced in his Toulon discourse, Sarkozy announced that 'without doubt, this crisis will mark the true start of the twenty-first century, the moment when everyone will understand that it was time to change' ${ }^{25}$. At Argonay, Sarkozy proposed the need for moralisation, transparency and protection. He announced a new strategic investment fund of $€ 26$ billion, the appointment of Réné Ricol to the position of National Credit Mediator and structural reforms such as opening businesses on Sundays.

In this speech, Sarkozy framed the responsibility for the crisis as lying outside France, but he accepted the responsibility of the French State to respond to it, and to act sooner rather than later. He continued to advocate the idea of a summit, in the form of a new Bretton Woods, thus reinforcing his commitment to fundamental changes to the global financial system. Table 7.6 demonstrates a similar media response to that of the speech at Toulon, with slightly more agreement with his policy proposals and a majority of overall support for Sarkozy. Le Monde illustrated such support for Sarkozy, saying that 'it remains that the style of Nicolas Sarkozy, sometimes disparaged, has played more in his favour' and quoted a German diplomat who said 'during a crisis, hyperactivity becomes energy, arrogance becomes tenacity, unpredictability becomes pragmatism' 26 (Ferenczi 2008). This demonstrated a sense of public support for Sarkozy's leadership in a time of crisis. 


\begin{tabular}{|l|l|l|l|l|}
\hline & Causality & Severity & $\begin{array}{l}\text { Policy } \\
\text { proposals }\end{array}$ & $\begin{array}{l}\text { Support for } \\
\text { speaker }\end{array}$ \\
\hline Agrees & & 1 & 5 & 6 \\
\hline Disagrees & & & 3 & 2 \\
\hline $\begin{array}{l}\text { No comment/ } \\
\text { neutral }\end{array}$ & 10 & 9 & 2 & 2 \\
\hline
\end{tabular}

Table 7.6 Media response to Sarkozy's 23 October 2008 speech

\section{December 2008: Sarkozy's Douai address}

Sarkozy's third key speech was delivered at Douai, where he affirmed that the crisis was not a passing phenomenon. In this address, he also envisaged a longer-term framing of the crisis and proposed how France would emerge from it. In explaining the protracted nature of the global financial crisis, Sarkozy acknowledged the looming problem of higher unemployment: 'it is unemployment that strikes up the crisis of confidence which precedes the economic crisis. ${ }^{27}$ This framed the crisis as a chain of events. The address focused on government measures, especially in the explanation of the $€ 26$ billion stimulus plan. The stimulus was to be spent on public sector investments and loans for the French automotive industry, which employed, directly or indirectly, 10 per cent of the working population. Sarkozy portrayed this 'massive investment plan' ${ }^{28}$ as a historic responsibility to remake France in terms of infrastructure, universities and research.

The media response to the Douai address continues the pattern of the response to Sarkozy's other speeches. Table 7.7 demonstrates overall support for Sarkozy, but slightly higher disagreement with his policy proposals. Two journalists for Le Figaro called the policy proposal in this speech 'an arsenal of anti-crisis measures $^{29}$ (Lachevre and Visot 2008b).

\begin{tabular}{|l|l|l|l|l|}
\hline & Causality & Severity & $\begin{array}{l}\text { Policy } \\
\text { proposals }\end{array}$ & $\begin{array}{l}\text { Support for } \\
\text { speaker }\end{array}$ \\
\hline Agrees & & 1 & 3 & 5 \\
\hline Disagrees & & 1 & 4 & 2 \\
\hline $\begin{array}{l}\text { No comment/ } \\
\text { neutral }\end{array}$ & 8 & 6 & 1 & 1 \\
\hline
\end{tabular}

Table 7.7 Media response to Sarkozy's 4 December 2008 speech

\section{January 2009: Lagarde's optimism for the New Year}

Lagarde's 2009 New Year address was more reflective than her previous speeches. It conveyed optimism for the year ahead. There appeared to be a deliberate absence of explanation and accounting for the crisis in this address in order to 
focus on asserting the success of crisis management to date, as well as on future plans. As such, with the early manifestation of the crisis behind her, Lagarde outlined four reasons for hope in 2009, including positive economic signs such as inflation coming down again to 1.6 per cent in November 2008, even though it had gone as high as 3.6 per cent in July 2008. Other reasons were the induction of a new administration in the United States led by President, Barack Obama, and Secretary of the Treasury, Timothy Geithner; Europe retaining the unity and international standing it had gained under the French presidency; and the government's actions, such as the stimulus plan. There was little discussion of Lagarde's New Year address in the papers analysed in this chapter, suggesting just how much of the media spotlight on this matter was focused on Sarkozy. Where reports were found, there was little disagreement with Lagarde's framing of the crisis (Table 7.8).

\begin{tabular}{|l|l|l|l|l|}
\hline & Causality & Severity & $\begin{array}{l}\text { Policy } \\
\text { proposals }\end{array}$ & $\begin{array}{l}\text { Support for } \\
\text { speaker }\end{array}$ \\
\hline Agrees & & 1 & & 2 \\
\hline Disagrees & & & 1 (implicitly) & \\
\hline $\begin{array}{l}\text { No comment/ } \\
\text { neutral }\end{array}$ & 2 & 1 & 1 & \\
\hline
\end{tabular}

Table 7.8 Media response to Lagarde's 13 January 2009 speech

\section{January 2009: Noyer's strategies for French and European finance}

Noyer delivered his address 'Global financial crisis: public and private strategies in response to the crisis' 30 in the United Arab Emirates, on 21 January 2009. This was a key speech, as Noyer readdressed two key themes of the crisis - its nature and the policies in response to it - and delivered it in an international location. In this speech, Noyer simplified the definition of the crisis. He called it a crisis of liquidity that began in August 2007 and moved to affect the economy on a large scale. Noyer noted that, in addition to a crisis of liquidity, it was also a crisis of securitisation, where the packaging of debt into a financial product, for the purpose of rating and trading, did not discriminate against bad debt. After this, Noyer provided a further explanation of the crisis by describing how the instability of financial structures had been concealed and the chain reaction this had initiated. According to Noyer, there were two fundamental realities: first, responsibility for the crisis was concentrated in the hands of financial institutions; and second, in order to remedy the consequences of this, structural innovation was necessary. Having established the causes, and thereby the responsibility for the crisis in the financial sector, Noyer ushered in the role of the State. According to him, the State held the responsibility to modify the policy 
budget, which in turn would restart the economic machine. Noyer referred, in addition to the French domestic economy, to a wider plan for Europe, especially in light of the French EU Presidency. The media response to Noyer's address largely ignored his framing of the causes of the crisis and his overall leadership, although there was some disagreement about his severity framing and the policies that his speech put forward.

\begin{tabular}{|l|l|l|l|l|}
\hline & Causality & Severity & $\begin{array}{l}\text { Policy } \\
\text { proposals }\end{array}$ & $\begin{array}{l}\text { Support for } \\
\text { speaker }\end{array}$ \\
\hline Agrees & & 1 (implicitly) & 2 (implicitly) & 1 \\
\hline Disagrees & & 1 & 1 & 3 \\
\hline $\begin{array}{l}\text { No comment/ } \\
\text { neutral }\end{array}$ & 4 & 2 & 1 & \\
\hline
\end{tabular}

Table 7.9 Media response to Noyer's 21 January 2009 speech

\section{March 2009: Sarkozy's Saint-Quentin address}

At Saint-Quentin, Aisne, Sarkozy delivered the last key speech during this chapter's 12-month period of analysis. In this address, Sarkozy referred to values and morality while reiterating that this was an unprecedented crisis. A notable departure from his earlier speeches was evident in the explicit reference to public opinion, which had manifested in protests through early 2009. Sarkozy acknowledged this dissent, saying, 'my task is to listen to those who protest, but I also have the responsibility to listen to those who do not march in protest' ${ }^{31}$ It is in this speech that one can perceive the type-3 framing at play. Sarkozy claimed that the crisis gave new freedoms to think, to imagine, to act and to invent France's future. In even more straightforward terms, Sarkozy affirmed that 'it is necessary to benefit from the crisis' . ${ }^{32}$ Sarkozy insisted, however, that in order to realise these freedoms and opportunities, everyone had a moral responsibility, including himself.

Table 7.10 demonstrates that, despite continuing public protests and declining popularity ratings, there was still overall support for Sarkozy in the media. In the context of the speech at Saint-Quentin, Libération posed the question: 'What to say to reassure a public opinion which repudiates him in the opinion polls? Speak of values and landmarks' ${ }^{33}$ (Guiral 2009b).

In contrast with earlier media responses, some articles after this speech took electoral issues into consideration; 'to have his nose on the crisis does not prevent him having an eye on his campaign promises and the presidential election of $2012^{\prime 34}$ (Cornudet 2009). With the 2012 election in mind, other articles discussed the post-crisis era. 
After Toulon in September at the start of the crisis, Douai in December on the stimulus plan, Saint-Quentin is supposed to open perspectives on the post-crisis. All of these speeches are small stones scattered on the path which will take Sarkozy back to the Elysée in 2012. ${ }^{35}$ (Guiral 2009a)

\begin{tabular}{|l|l|l|l|l|}
\hline & Causality & Severity & $\begin{array}{l}\text { Policy } \\
\text { proposals }\end{array}$ & $\begin{array}{l}\text { Support for } \\
\text { speaker }\end{array}$ \\
\hline Agrees & & 4 & 4 & 10 \\
\hline Disagrees & & & 1 & \\
\hline $\begin{array}{l}\text { No comment/ } \\
\text { neutral }\end{array}$ & 10 & 6 & 5 & \\
\hline
\end{tabular}

Table 7.10 Media response to Sarkozy's 24 March 2009 speech

\section{Framing the financial crisis in France: analysis and discussion}

The very central role of Sarkozy aside, the three actors assumed markedly different roles in the framing of the financial crisis. On the whole, however, there was little disagreement between their crisis rhetoric. The French leaders paid little attention to the cause of the crisis, which was explained by the consequences of the US sub-prime crisis in a highly globalised economy, and this explanation was questioned to a minimal extent, if at all, by the media and the public. Rather, the framing contest in France was centred on the severity of the crisis and the proposed measures and changes to policy.

Sarkozy's key speeches during the 12-month period of analysis until $31 \mathrm{March}$ 2009 maintained the underlying themes of opportunism and a break with the past. The public response to Sarkozy's framing of the crisis fluctuated between support and opposition. While one could infer that the French population eagerly accepted Sarkozy's call for a new international financial order, it is necessary, however, to consider the socialist opposition to fully understand the public response to Sarkozy and his crisis framing. As one academic commented: 'A crisis in global capitalism provides the French political left with a blessed opportunity to rebuild its strength in a country traditionally uneasy about so many tenets of the free market ideology and always prone to revert to state-centred solutions' (Charnoz 2008:1). The political left in France, however, was not able to mount a convincing or popular response to Sarkozy, especially because the Parti Socialiste (PS) had recently been undergoing leadership changes.

Le Figaro-LCI survey for the week ending 27 November asked respondents: 'In your opinion, if she was in power would Martine Aubry [the newly elected leader of the PS] do better, worse or neither better nor worse than Nicolas Sarkozy?' Twenty-four per cent of respondents said Aubry would do better, 31 per cent thought she would do worse and 44 per cent said neither better nor 
worse (Le Figaro-LCI Politoscope 2008:15). In comparison with his nearest competitor, therefore, Sarkozy was viewed by some margin as doing a 'better job'. In a later Le Figaro-LCI survey, on 26 March 2009, respondents were questioned specifically about Sarkozy's crisis leadership. Only 46 per cent of respondents said they had confidence in Sarkozy in facing the crisis (Le Figaro-LCI Politoscope 2009:10).

The media response to Lagarde's framing of the global financial crisis was more difficult to determine compared with that of Sarkozy. Lagarde appeared to play more of a spokeswoman role than participating actively in framing or crisis exploitation. Her role was described as that of a 'back office executive' (de Buttet 2009). The limited visibility of Lagarde's rhetoric in the media places greater weight on public opinion data in order to analyse the response to her crisis framing. Although French public opinion of Lagarde was generally quite favourable, she won greater respect abroad than at home, where her reputation came under increasing attack. A key point of contention was her (with hindsight cavalier) suggestion that 'the big risk is behind us' (The Economist 2008), even though financial markets were continuing to fall at the time.

There was disparity, however, between the media response and public opinion data, because according to Paris-Match ratings in October 2008, Lagarde's popularity jumped by 5 points to 46 per cent, at a time when Sarkozy's rating remained at 44 per cent (The Economist 2008). Shortly after her key speech in early 2009, Lagarde's rating rose to 52 per cent in February, seemingly exempting her from the otherwise growing public dissatisfaction (TF1 2009).

Overall, the public's opinion of Christian Noyer was best exemplified by his presence, or lack thereof, in the French media. Tables 7.1, 7.5 and 7.9 demonstrate no comment or neutrality in most of the media responses after Noyer's key speeches. Noyer is for the most part not a visible public figure, especially in comparison with Sarkozy. This can be attributed to two main factors. There was the prominent presence of Sarkozy and the strong public interest in all aspects of his energetic leadership style, especially during the French EU Presidency. On the other hand, the role and visibility of Banque de France had diminished significantly after the creation of the ECB (de Buttet 2009). In effect, there was more public interest in French, and European, banking policy than in the central bank governor himself.

In France, the government's crisis-exploitation efforts were characterised largely by type-3 opportunism and a concerted attempt to combine short and long-term management strategies. During the global financial crisis, the attempt to alter levels of political support in France was focused primarily on public policies, situated in the bigger picture of policy reform. Effectively, a 'crisis as opportunity' approach prevailed in Sarkozy's rhetoric in particular. This crisis framing, however, must also be considered explicitly within the context of three 
key distinctive features of the French case: French public opinion and political culture; the lack of significant political opposition; and the wider context of the crisis on the European, even global, stage.

\section{French political culture: public opinion and state structure}

French political culture is unique in terms of its state-citizen relationship and has strong historical undertones that have continued to influence French politics throughout the crisis period. According to David Bell (2002:15), 'The French state plays a much larger part in civil society (in both economics and social life) than in some other countries. The state has provided a continuity in the life of the nation and that has not been seriously challenged in the past.' The national leaders' framing and utilisation of the crisis cannot be analysed in isolation from the deep-seated traditions of French political culture, particularly with regard to public opinion and the structure of the State. Policy proposals and state actions were publicly questioned early in 2009 by way of unseasonal protests as the crisis began to take hold at an increasingly individual level. The French tendency to protest is considered quite normal, but it follows a routine whereby the months that flank summer-May and September - tend to be the peak of the protest season (Ganiko 2009). Nicholas Bavarez, an economic commentator, gave a succinct explanation of this culture, referring historically to the Jacquerie uprising of 1358, and conclusively classifying recurrent revolts and violence as epitomising French exceptionalism ${ }^{36}$ (The Economist 2009b).

In addition to protest, the structure of the French State was a crucial contextual factor, which influenced how the global financial crisis played out in France. France responds badly to economic shocks partly because of a lack of civic institutions below the State (The Economist 2009b). The highly centralised system of governance therefore did not translate into comprehensive crisis management.

Moreover, concern about unemployment, which prompted the winter protests (especially in the automotive industry, which at the time employed up to 10 per cent of the working population), was influenced by the pre-crisis labour structure. France's two-tier labour market overly protected permanent jobs and thus encouraged companies to hire most workers on flexible short-term contracts. Once the crisis hit, it was these non-permanent jobs that were being shed (The Economist 2009a). This labour structure sparked the public's concern about rising unemployment and the State's inability to alleviate this. In the context of French political culture and the history of protesting, the public response to the global financial crisis was manifested in public protests. Therefore, French political culture - particularly the relationship between public opinion and the structure of the State - was one of the major contextual factors that influenced leaders' framing of and the public response to the global financial crisis. 


\section{A lack of political opposition}

Sarkozy's, and to a lesser extent Lagarde's, success in crisis framing was made possible by a chronic lack of politically credible counter-frames. This issue, although noticeable in the leaders' speeches, became evident through deeper analysis of the media response and public opinion data. The crisis-exploitation framework set out in Chapter 2 proposes that there are two spheres of a framing contest: the political sphere and the policy sphere. In the French case, however, a political contest was almost non-existent at the time. As a non-political actor, Noyer was by definition not part of the political crisis-exploitation game from the outset. On the other hand, Sarkozy and Lagarde had political careers potentially at stake. The Parti Socialiste, however, the key opposition party, failed to mount a response to the framing of the crisis by Sarkozy and Lagarde. Therefore, it is the policy crisis-exploitation matrix that is most relevant to the French case (cf. Table 2.2, Chapter 2).

According to 'the policy game' and taking into consideration the opportunism of the type- 3 frame, French leadership projected an image of itself as an advocate for change, rhetorically pressing for a policy paradigm shift, but in fact implementing incremental change, at least in the short to mid-term. The crisis-exploitation framework also proposes that

change-oriented players have to decide whether they feel that the crisis has created the need and the opportunity to press for a wholesale overturning of the policy's ideological and/or intellectual underpinnings...or whether to momentarily content themselves with advocating more incremental changes. (Boin et al. 2009:90)

Public opinion, especially visible in the unusually high number of protests in the winter months, forced Sarkozy and Lagarde to turn their attention towards the everyday difficulties increasingly faced by the French population. This, at least momentarily, made a 'policy paradigm shift' less desirable.

Consequently, the grand agenda for change, exemplified by the pre-crisis movement for the 'the law for economic modernisation' 37 as well as Sarkozy's call in September 2008 for a new international financial order, was contested by status quo players in particular change-averse, protest-minded segments of public opinion. The policy game in France can therefore be situated in box IV of 'the policy game' - negotiated incremental adjustment.

\section{France in a truly global financial crisis}

Following the crisis-exploitation framework, type-3 frames attempt to endogenise a crisis - to find fault in the present system and call for change (see Chapter 2, this volume). The French case study is consistent with this frame to the extent that the key players identified faults at the systemic level. At the same time, 
however, the key players exogenised the responsibility issue by using the crisis to establish that the French State was not to blame. In terms of causality and responsibility, there was little or no disagreement across the leaders' speeches and the public response. There was seamless consistency between Sarkozy, Lagarde and Noyer, each of whom named the origins of the crisis in the US sub-prime crisis. In effect, their narrative emphasised the global level, portraying the French economy as mired in a financial system that, as Sarkozy highlighted, had betrayed the values of capitalism.

With the benefit of holding the EU Presidency at a critical time, Sarkozy moved beyond his national platform in framing the crisis. He pushed the initiative for a global conference of the G20 nations, which was realised in November 2008 in Washington, DC, and followed up by the summit in London in early April 2009. His approach to leading the financial crisis at the regional European level did not, however, meet with great enthusiasm in other EU member states, as evidenced by the German Finance Minister, who 'clearly opposed the principle of "international macroeconomic regulation", a line that seemed to open the way for the French idea of a European economic government' (Charnoz 2008:2). This suggests that there was an underlying French agenda to push for greater economic integration in the European Union.

Once again, the political culture of France is highly relevant here - in particular, the French dirigiste tradition. 'The dirigiste outlook currently goes against the grain of globalisation and free market fashions everywhere else in the Western world. There has, as with other Western societies, been a withdrawal of the state since the 1980s but not to the same extent as elsewhere' (Bell 2002:15). The dirigiste tradition came to the fore in this crisis period. 'Despite calls from the Americans to do more to lift consumer demand, [the French] stimulus plan relies heavily on front-loading investment in infrastructure...in line with their dirigiste tradition' (The Economist 2009c). This tradition not only reinforces the uniqueness of the French State, it demonstrates the differences between the crisis responses in the major economies of the world.

Sarkozy's combined French and EU leadership during the early crisis invites an interesting analysis of his personal leadership style that can be touched on only briefly in this chapter. Sarkozy's framing of the crisis was wrought with wider policy and political implications. Moreover, Sarkozy projected an unfaltering confidence in his own persuasive abilities. Complementary to this, Lagarde maintained an optimistic demeanour across her key speeches and Noyer consistently maintained support for government policy proposals. According to McLennan (2009:2), one of the key rules in crisis leadership is confidence before realism; leaders who succeed in times of crisis outwardly radiate confidence, plan contingencies and 'push forward with their gut instinct'. Sarkozy certainly fit that bill during the period studied here. 
The French case study suggests that national leaders' crisis framing, as well as the public response to this, cannot be viewed in isolation from its political context. French political culture, a lack of political opposition and the EU and global platforms provided a valuable complement to the crisis-exploitation analysis. In sum, national contextual factors, individual leadership style and crisis opportunism shaped French crisis management in a truly global financial crisis.

\section{References}

About-France 2009, 'The French press: the dailies', About-France, viewed 27 April 2009, <http://about-france.com/french-newspapers.htm>

Angus Reid Global Monitor 2008, 'French clearly worried about financial crisis', Angus Reid Global Monitor, 28 September, viewed 27 April 2009, $<$ http://www.angus-reid.com/polls/view/ french_clearly_worried_about_financial_crisis/>

Bacqué, R. 2008, 'Christian Noyer Banquier antistress', Le Monde, 24 October.

Banque de France 2004, Organisational Structure: Christian Noyer's biography, Banque de France, viewed 26 May 2009, $<$ http://www.banque-france.fr/gb/instit/orga/noyer.htm>

Bell, D. S. 2002, French Politics Today, Manchester University Press, Manchester.

Bohineust, A. 2008, 'Le gendarme des banques appelle a la vigilance', Le Figaro, 27 June.

Boin, A., 't Hart, P. and McConnell, A. 2009, 'Crisis exploitation: political and policy impacts of framing contests', Journal of European Public Policy, vol. 16, no. 1, pp. 81-106.

Charnoz, O. 2008, 'A French perspective on the financial crisis', in J. Kirton (ed.), The G20 Leaders Summit on Financial Markets and the Global Economy, University of Toronto, Toronto, viewed 30 May 2009, <http://www.g20.utoronto.ca/g20leadersbook/index.html>

Chavigné, J.-J. 2008, 'Chronologie de la crise financière 2007-2008', Democratie-Socialisme.org, 6 October, viewed 30 April 2009, <http://www.democratie-socialisme.org/spip.php?article1643>

CNN 2007, 'French kiss, lunches hinder reform', CNN, 30 May, viewed 31 May 2009, $<$ http://www.cnn.com/2007/WORLD/europe/05/30/france.lunches.reut/index.html>

Connexion 2009, 'French media read all about it', The Connexion, November, viewed 27 April 2009, $<$ http://www.connexionfrance.com/expatriate-news-article.php?art=276> 
Cornudet, C. 2008, 'Les dessous d'une préparation au cordeau', Les Echos, 4 December.

Cornudet, C. 2009, 'L'œil rivé sur 2012, Nicolas Sarkozy refuse de se laisser dévier par la crise', Les Echos, 24 March.

de Buttet, G. 2009, Telephone interview with author, 18 May.

Economist 2008, 'On Lagarde', The Economist, 23 October.

Economist 2009a, 'A time of troubles and protest', The Economist, 22 January.

Economist 2009b, 'Super-Sarko falls to earth', The Economist, 16 April.

Economist 2009c, 'Vive la difference!', The Economist, 7 May.

Economist Intelligence Unit 2009, 'Economist Intelligence Unit monthly reports on France', The Economist, September 2008 - March 2009, viewed 27 April 2009, <http://www.eiu.com>

EuroFin 2008, 'Speaker's CVs: Lagarde', EuroFin, EuroFin Conference, Nice, 11-12 September, viewed 26 May 2009, <http://www.emcnet.eu/doc/WEBSITE\%20CVs/LAGARDE.pdf>

Ferenczi, T. 2008, 'Nicolas Sarkozy, un président pour temps de crise?', Le Monde, 24 October.

Ganiko, I. Telephone interview with author, 5 May 2009.

Guiral, A. 2008, 'Le laisser-faire, c'est fini', Libération, 26 September.

Guiral, A. 2009a, 'Sarkozy vend sa pilule du lendemain qui chante à Saint-Quentin', Libération, 24 March.

Guiral, A. 2009b, ‘Reportage: Nicolas Sarkozy en mission diversion', Libération, 25 March.

Jeudy, B. 2008, 'Nicolas Sarkozy veut "refonder le capitalisme"', Le Figaro, 26 September.

Jeudy, B. and Visot, M. 2008, 'Relance: comment Sarkozy prépare son plan', Le Figaro, 2 December.

Lachevre, C. 2008, 'Le plan de soutien français bien reçu des économistes', Le Figaro, 16 October.

Lachevre, C. and Visot, M. 2008a, 'Un budget “de crise" pour 2009 marque par le creusement des déficits et l'austérité', Le Figaro, 27 September.

Lachevre, C. and Visot, M. 2008b, 'La relance massive de Nicolas Sarkozy', Le Figaro, 4 December.

Lagarde, C. 2008a, Projet de loi de finances pour 2009, Speech, 26 September, viewed 29 May 2009, <http://www.budget.gouv.fr/discours-presse/ discours-communiques_budget.php?type $=$ discours\&id $=619 \&$ rub $=>$ 
Lagarde, C. 2008b, Plan national pour assurer le financement de l'économie et restaurer la confiance, Speech, 15 October, viewed 29 May 2009, $<$ http://www.budget.gouv.fr/discours-presse/ discours-communiques_budget.php?type $=$ discours $\& i d=623 \&$ rub $=>$

Lagarde, C. 2009, Voeux a la presse, Speech, 13 January, viewed 29 May 2009, $<$ http://www.budget.gouv.fr/discours-presse/ discours-communiques_budget.php?type $=$ discours \&id $=644 \&$ rub $=>$

Le Figaro-LCI Politoscope 2008, 'Season 3, wave 13', 27 November, viewed 9 May 2009, <www.lefigaro.fr/assets/pdf/oway27nov.pdf>

Le Figaro-LCI Politoscope 2009, 'Season 3, wave 27', 26 March, viewed 9 May 2009, $<$ http://www.opinion-way.com/pdf/lefigaro-lci-politoscope-saison3vague27.pdf>

Les Echos 2008, 'Crise financière: Gueant légèrement plus rassurant que Sarkozy', Les Echos, 29 September.

McLennan, K. 2009, 'Neuroscience and evolutionary psychology assist our leadership minds as we respond to the global financial crisis', Leadership Reflections, February, Heidrick \& Struggles Leadership Consulting, Sydney.

Missiroli, A. 2009, Europe: the state of the union, Address given at the National Europe Centre, The Australian National University, Canberra, 22 April.

Noyer, C. 2008a, Assemblée générale de l'Office de Coordination bancaire et financière, Speech, 25 June, viewed 29 May 2009, $<$ http://www.banquedefrance.fr/fr/instit/telechar/discours/2008/ disc20080625.pdf>

Noyer, C. 2008b, Réflexions sur la crise, Speech, 21 October, viewed 9 May 2009, $<$ http://www.banque-france.fr/fr/instit/telechar/discours/2008/ disc20081020.pdf>

Noyer, C. 2009, Crise financière mondiale: stratégies publiques et privées pour faire face à la crise, Speech, 21 January, viewed 9 May 2009, $<$ http://www.banque-france.fr/fr/instit/telechar/discours/2009/ disc20090123.pdf>

Sarkozy, N. 2008a, Discours de M. le Président de la République au Zénith de Toulon, Speech, 25 September, viewed 9 May 2009, $<$ www.elysee.fr/download/?mode=press\&amp;filename $=$ 29.09_Discours_Toulon_du_30.pdf $>$

Sarkozy, N. 2008b, Discours de M. le Président de la République, Argonay, Haute-Savoie, Speech, 23 October, viewed 9 May 2009, $<$ www.elysee.fr/download/?mode=press\&amp;filename=argonay.pdf $>$ 
Sarkozy, N. 2008c, Plan de relance de l'économie francaise, Speech, 4 December, viewed 9 May 2009,

$<$ www.elysee.fr/download/?mode=press\&amp;filename=04.12_DOUAI.pdf $>$

Sarkozy, N. 2009, Discours de M. le Président de la République à Saint-Quentin, Speech, 24 March, viewed 9 May 2009,

$<$ http://www.elysee.fr/documents/index.php?mode=view\&lang $=$ fr\&cat_id=7\& press_id=2463>

TF1 2009, 'Lagarde épargnée par la crise', TF1, 10 February, viewed 29 May 2009, <http://tfl.lci.fr/infos/france/politique/ 0,,4253136,00-lagarde-epargnee-par-la-crise-.html>

\section{Endnotes}

1 'L'Union fait la force.'

2 'Le loi pour le modernisation de l'économie.'

3 Petites et Moyennes Entreprises.

4 'Un discours qui marque incontestablement le début de la phase 2 du quinquennat.'

5 'Coup de froid.'

6 'Cette situation a été à l'origine d'une généralisation de la perception selon laquelle les opportunités $\mathrm{d}^{\prime}$ investissement dans des actifs apparemment de bonne qualité étaient quasi illimitées et a altéré le jugement des acteurs.'

7 'Un ensemble de bonnes pratiques.'

8 'Alors qu'en Bourse les Banques étaient sérieusement malmenées hier, la Commission bancaire...se voulait plutôt optimiste.'

9 'Une crise de confiance sans précédent.'

10 'La crise financière...n' est pas la crise du capitalisme. C'est la crise d'un système qui s'est eloigné des valeurs les plus fondamentales du capitalisme, qui en quelque sorte, a trahi l'esprit du capitalisme.'

11 'L'anticapitalisme n'offre aucune solution à la crise actuelle.'

12 'Le jour où il avait sonné la mobilisation contre la crise.'

13 'Le discours que Nicolas Sarkozy a prononcé à Toulon, le 25 septembre, marque son entrée en guerre contre la crise.'

14 'Le projet de loi de programmation des finances publiques nous amène en effet jusqu'en 2012.'

15 'Les turbulences qui perdurent sur les marchés financiers internationaux depuis un an refletent les conséquences d'une purge profonde du secteur financier americain.'

16 'La crise financière qui sévit depuis un an a finalement impacté l'économie mondiale et provoque un net ralentissement en France.'

17 ‘30 600 postes seront supprimés dans la fonction publique contre 22900 en 2008. C'est un peu moins que la promesse de ne pas remplacer un fonctionnaire sur deux partant à la retraite.'

18 'Plan national pour assurer le financement de l'économie et restaurer la confiance.'

19 'La crise que nous vivons est excessive.'

20 'Ce que nous proposons c'est tout le contraire du plan Paulson...l'Etat americain propose de prendre à sa charge les actifs les plus mauvais...en France, l'Etat n'achetera pas d'actifs. Il pretera aux banques.'

21 'Elles peuvent aussi servir à faire d'une pierre deux coups en aidant à moyen terme les enterprises à se financer.'

22 'Au premier rang.'

23 'Grâce, notamment, au rôle leader de la France, l'Europe s'est organisée.'

24 'Inaudible dans une salle de 100 personnes.'

25 'Cette crise marqerua sans doute pour l'histoire le commencement veritable du XXIe siècle, le moment où tout le monde aura compris qu'il était temps de changer.' 


\section{Framing the global economic downturn}

26 'Reste que le style de Nicolas Sarkozy, parfois décrié, a plutôt joué en sa faveur. En période de crise, l'hyperactivité devient de l'énergie, l'arrogance de la ténacité, l'imprévisibilité du pragmatisme.'

27 'C'est autour du chômage que se noue la crise de confiance qui precipite la crise économique.'

28 'Plan d'investissement massif.'

29 'Un arsenal anticrise.'

30 'Crise financière mondiale: stratégies publiques et privées pour faire face à la crise.'

31 ' $J$ 'ai le devoir d'entendre ceux qui manifestent, mais j'ai également la responsabilité de ceux qui ne défilent pas.'

32 'Il faut profiter de la crise.'

33 'Que dire pour rassurer une opinion publique qui le désavoue dans les sondages? Parler des "valeurs", donner des "repères".'

34 'Avoir le nez sur la crise ne l'empêche pas d'avoir un œil sur ses promesses de campagne et sur l'élection présidentielle de 2012.'

35 'Après Toulon en septembre, au début de la crise, Douai en décembre, sur le plan de relance, Saint-Quentin est censé ouvrir des perspectives sur l'après-crise. Tous ces discours sont des petits cailloux semés sur le chemin qui doit ramener Sarkozy à l'Elysée en 2012.'

36 'L'exception française.'

37 'Loi de modernisation de l'économie.' 